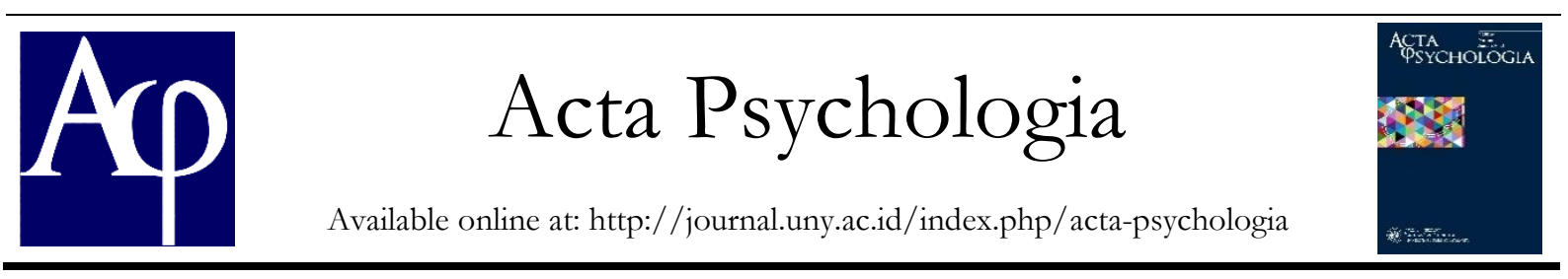

\title{
Pembentukan Identitas Diri pada Remaja yang Diadopsi
}

\author{
Astri Anggraeni \\ Jurusan Psikologi, Fakultas Ilmu Pendidikan, Universitas Negeri Yogyakarta; \\ Jl. Colombo No. 1 Sleman Yogyakarta, 55281 \\ astriastr08@gmail.com
}

\begin{abstract}
Abstrak
Penelitian ini bertujuan untuk mengetahui proses pembentukan identitas diri pada remaja yang adopsi dilihat dari aspek eksplorasi dan komitmen, serta sumber acuan yang mempengaruhinya. Penelitian ini menggunakan pendekatan deskriptif kualitatif. Subjek penelitian adalah dua remaja adopsi berusia 18-21 tahun, sudah mengetahui dirinya diadopsi, dan masih berada di bawah pengawasan orang tua adopsi. Data diambil melalui wawancara yang kemudian dianalisis dengan cara reduksi data, penyajian data dan penarikan kesimpulan. Data yang didapat kemudian diuji keabsahannya dengan ketekunan pengamatan, triangulasi sumber dan metode, serta perpanjangan keikutsertaan. Hasil penelitian menunjukkan eksplorasi identitas kedua subjek berada pada in crisis, namun komitmen pada dua subjek berbeda. Komitmen subjek BAT lebih nyata dibandingkan subjek RA yang cenderung kabur. Perbedaan ini dipengaruhi oleh inisiatif diri, pengalaman masa kecil, dukungan orang tua, serta tuntutan lingkungan sekitar terhadap identitas yang dipilih. Di samping itu, sumber yang banyak berpengaruh dalam proses pencarian identitas diri secara berurutan adalah keluarga adopsi, reference group, dan keluarga kandung.
\end{abstract}

Kata Kunci: identitas diri, remaja adopsi, kualitatif

\begin{abstract}
This study aimed to describe the process of identity formation among adopted adolescence based on the aspect of their exploration and commitment, and their most influential sources. This studey used descriptive-qualitative methods. The subjects of this study were two adopted teenagers who are in their late adolescence or aged 18-21 years, already knowing the fact they were adopted, and still under guardianship of their adoptive parent. The data were collected through interviews. The data were analyzed using data reduction, data display and conclusion drawing. Futhermore, perseverance of observation, data and methodological triangulation, also extension of attendance were used to check the validity of the data. This research found that identity exploration of both subjects are in crisis, but the commitment given by subject BAT is more real than the commitment of subject RA which rather vague. This differences were affected by initiative, childhood experiences, parental support, and demand from environment according their chosen identity. In addition, the most influential sources of both subjects sequentially came from their adoptive families, reference group and biological families.
\end{abstract}

Keywords: self-identity, adopted adolescence, qualitative

\section{Pendahuluan}

Anak adopsi dinyatakan sebagai individu yang bukan keturunan suami istri, namun ia diambil, dipelihara dan diperlakukan seperti halnya anak keturunan sendiri (Adel, 2018). Keberadaan anak adopsi dalam suatu keluarga bukan tanpa alasan. Yustiana (2017), mengemukakan alasan keluarga mengadopsi anak adalah karena ketidakhadiran anak kandung dan ingin memiliki anak untuk menjaga masa depan dan masa tua nanti, menjaga keharmonisan hubungan pernikahan, keyakinan bahwa kehadiran anak adopsi dapat merangsang kehamilan, perasaan iba terhadap anak terlantar atau anak yang tidak mampu dirawat orang tuanya, titipan teman dan atau untuk menambah atau memperoleh tenaga kerja. 
Keputusan mengadopsi anak bukanlah tindakan yang salah, hanya saja hendaknya dilakukan melalui banyak pertimbangan terutama menyangkut penjelasan identitas anak di kemudian hari (Mulyadi, 1999). Pengungkapan identitas ini perlu dilakukan karena anak perlu tahu siapa dirinya agar mereka tidak mengalami kebingungan identitas. Terlebih identitas adopsi merupakan identitas yang ditetapkan karena keadaan, dimana individu terlahir atau ditakdirkan dalam kondisi tertentu tanpa bisa memilih.

Pertanyaan mengenai identitas lebih sering terjadi pada masa remaja, karena pada masa ini remaja dihadapkan dengan pertanyaan-pertanyaan seputar dirinya yang kemudian akan diungkapkan melalui penemuan identitas diri. Erikson menambahkan adanya identitas diri akan membuat remaja memiliki pandangan yang jelas tentang diri sendiri, tidak mudah meragukan dirinya, serta mengenal peranannya dalam masyarakat (Dela, 2016 ).

Remaja yang mengalami kebingungan identitas cenderung memiliki perkembangan psikososial yang negatif (Schwartz dkk, 2011). Kebingungan itu dapat berupa menarik diri, mengasingkan diri dari dunia pertemanan dan keluarga, atau malah membenamkan dirinya pada dunia pertemanan dan kehilangan identitasnya di dunia pertemanan (Santrock, 2007). Sebaliknya remaja yang mampu menyelesaikan konflik identitas, emosinya cenderung stabil, well-being dan self- esteem nya lebih positif serta mampu melakukan penyesuaian sosial dan akademik dengan baik (Dela, 2016).

Proses pembentukan identitas yang dilakukan remaja di atas, dilakukan sebagai bentuk eksperimentasi peran terhadap berbagai macam identitas yang mungkin saling bertentangan. Pada kondisi ini kemampuan diri dan dukungan lingkungan sangat berpengaruh dalam membentuk identitas individu apakah mereka mampu dalam menemukan identitas optimalnya atau malah mengalami kebingungan identitas. Hanya saja, bagi remaja adopsi, tugas pembentukan identitas diri ini harus ditambah dengan mengintegrasikan status adopsi ke dalam dirinya (Grotevant $\&$ Von Korff, 2011).

Beberapa penelitian seputar identitas diri dan anak adopsi menyatakan, proses pembentukan identitas diri akan lebih sulit dialami anak adopsi dibandingkan anak non adopsi (Frisk, 1964). Hal ini dikarenakan anak adopsi terutama yang memasuki masa remaja mengalami banyak permasalah mengenai adopsi seperti perasaan terbuang, perasaan tidak ada yang menyayanginya, memiliki banyak pertanyaan yang sulit dijawab seperti bagaimana kondisi keluarga kandungnya dan alasan mengapa mereka di adopsi (Child Welfare, 2014).

Anak adopsi yang memasuki masa remaja juga cenderung memiliki perilaku yang negatif seperti memiliki nilai yang rendah di sekolah, banyak terlibat dalam tindakan kejahatan dan kriminal, serta berpeluang kecil melanjutkan pendidikan ke jenjang berikutnya (Decker, 2009). Hal ini memperlihatkan bahwa remaja adopsi cenderung memiliki permasalahan dalam hal perilaku dan psikologis namun belum diketahui secara pasti apakah hal ini akan bertahan sampai dewasa atau tidak.

Dalam ranah keluarga, anak adopsi juga akan menghadapi kebingungan identitas karena memiliki beberapa perbedaan fisik, karakter, dan budaya dengan orang tua angkat (Dunbar \& Grotevant, 2004). Selain itu anak adopsi yang dihadapkan dengan perbedaan struktur keluarga dibandingkan dengan teman sebayanya berpotensi mengalami kebingungan identitas (Colaner \& Kranstuber, 2010). Sebaliknya, remaja adopsi yang banyak melalui pencarian identitas diri cenderung memiliki hubungan yang lebih sehat, well-being nya meningkat dan memiliki pandangan yang positif terhadap adopsinya (Brodzinsky, 2006). 
Di Indonesia sendiri, penelitian mengenai identitas diri memang sudah banyak dilakukan, hanya saja subjek yang dipilih masih seputar anak-anak yang memiliki perilaku bermasalah, anak dari keluarga yang bercerai atau anak yang tinggal di panti asuhan. Penelitian mengenai identitas diri pada anak adopsi baik ketika mereka masih kanak-kanak ataupun remaja masih sulit ditemukan padahal peluang penelitian ini masih sangat luas. Oleh karena itu, penelitian mengenai identitas diri pada remaja adopsi dirasa penting dilakukan mengingat individu yang sedang membentuk identitas cenderung mencaricari cerita yang koheren dengan dirinya yang kemudian direfleksikan untuk menilai kebermanfaatan hidupnya dan menghubungkan identitasnya dari masa lalu hingga masa sekarang (Mc Adam, 2001).

Berdasarkan latar belakang tersebut maka penulis tertarik untuk mengetahui bagaimana proses pembentukan identitas diri yang dilakukan remaja adopsi melalui analisis data kualitatif. Proses pembentukan identitas diri yang dimaksud mengacu pada teori yang disampaikan Marcia (1993) yaitu berdasarkan ada atau tidaknya eksplorasi dan komitmen yang diberikan. Di samping itu, penulis juga tertarik untuk mengetahui siapa saja sumber acuan yang paling berpengaruh dalam proses pembentukan identitas dirinya. Data yang di dapat kemudian di deskripsikan sesuai dengan proses pembentukan identitas diri yang telah mereka lakukan.

\section{Metode Penelitian}

\section{Jenis penelitian}

Penelitian ini menggunakan pendekatan kualitatif dengan jenis deskriptif.

\section{Waktu dan tempat penelitian}

Penelitian ini dilaksanakan di Yogyakarta dan Magelang. Waktu penulisan penelitian dilakukan mulai Oktober-Juni 2019.

\section{Subjek penelitian}

Subjek pada penelitian ini dipilih menggunakan teknik purposive dengan kriteria yang diajukan adalah remaja adopsi berusia 18-21 tahun (remaja akhir), sudah mengetahui bahwa dirinya merupakan anak adopsi, dan masih berada di bawah pengawasan orang tua adopsi.

\section{Teknik pengumpulan data dan instrumen}

Data diperoleh langsung dari subjek penelitian menggunakan wawancara mendalam kepada anak adopsi dan informan kunci. Adapun instrumen yang digunakan adalah peneliti, pedoman wawancara dan rekaman suara.

\section{Teknike Analisis data}

Analisis data dalam penelitian ini mengacu pada Miles dan Huberman (dalam Sugiyono, 2015) melalui tiga kegiatan yang terjadi bersamaan yaitu reduksi data, penyajian data dan penarikan kesimpulan. Data yang di dapat kemudian di uji keabsahannya melalui ketekunan pengamatan, triangulasi sumber dan metode serta perpanjangan keikutsertaan.

\section{Hasil Penelitian dan Pembahasan}

\section{Proses pembentukan identitas-elesplorasi}

Berdasarkan hasil analisis, diketahui bahwa eksplorasi kedua subjek berada pada tahap in criris yaitu suatu keadaan dimana subjek sedang mencari tahu, menelaah informasi, memiliki pertanyaan-pertanyaan mengenai identitas serta sedang berjuang membuat keputusan hingga akhirnya memberikan perhatian lebih terhadap keputusan tersebut. Hanya saja kapasitas dan inisiatif ekplorasi subjek BAT jauh lebih nyata dibandingkan subjek RA yang cenderung kabur. Pada tabel 1 dipaparkan rincian proses eksplorasi subjek.

Mengenai eksplorasi, kedua subjek mampu menunjukkan konsep diri, kepercayaan diri, dan penghargaan diri yang positif. Namun konsep diri subjek BAT 
tidak sebanding dengan kemampuan penyesuaian diri dengan lingkungan sosial. Menurut Calhun dan Accocela (1990) hal ini bisa disebabkan oleh pengalaman dengan lingkungan dan orang sekitar yang memberikan masukan mengenai akibat suatu perilaku. Akibat ini bisa menjadi bentuk yang positif maupun negatif. Hurlock (dalam Simanjuntak, 2009) menambahkan individu dengan konsep diri positif akan mengembangkan sikap percaya diri, harga diri, dan kemampuan melihat diri secara realistis yang mempengaruhi kemampuan penyesuaian sosial.

Tabel 1. Proses eksplorasi

\begin{tabular}{lll}
\hline & Subjek BAT & Subjek RA \\
\hline Konsep diri & - Memiliki konsep diri positif & - Konsep diri positif \\
& - Melakukan evaluasi diri positif & - Melakukan evaluasi diri positif \\
& - Tertarik menggali potensi & - Kurang tertarik menggali potensi \\
& & namun mampu menggambatkan diri \\
dengan jelas
\end{tabular}

Keberhasilan maupun kegagalan remaja dalam menyelesaikan krisis identitas guna membentuk identitas diri tidak dapat dipisahkan dari pengalaman-pengalaman yang dijalani remaja. Pada saat kecil subjek BAT mengalami perlakuan yang kurang mengenakkan dari ibu adopsinya dimana ia sering mendapat kekerasan fisik serta sangat dibatasi dalam berperilaku. Karena perlakuan ini subjek menjadi individu yang pendiam dan serba pasrah. Selain itu, ketika kecil subjek sering berpindah tempat sekolah ia kesulitan dalam menjalin hubungan dengan teman-temannya. Sehingga dapat dikatakan bahwa proses pembentukan identitas lebih banyak terjadi pada masa remaja dengan segala faktor dan konsekuensi yang didapatkan (Calhoun \& Acocella, dalam Dela, 2016).
Apabila kita melihat kondisi masa kecil dapat dilihat bahwa keluarga dari kedua subjek menggunakan pola asuh permisif, yang memberi sedikit arahan dan membiarkan remaja membuat keputusan sendiri. Pada subjek BAT, keluarganya masih kurang mempercayai keputusankeputusan yang dilakukan sehingga hubungan saling percaya antara kedua belah pihak kurang kuat. Sedangkan pada subjek RA orang tua memberikan kepercayaan diri yang tinggi pada sang anak begitu pula sebaliknya sehingga muncul hubungan saling percaya. Dariyo (2004) mengatakan kepercayaan diri tumbuh dari kehidupan kelompok sosial atau keluarga yang saling mempercayai antara satu dengan yang lain. 

Orang tua yang percaya kepada anak, maka anak akan tumbuh dengan karakteristik untuk mempercayai orang tua. Hal ini dikarenakan mereka hidup dan tumbuh dalam suasana hubungan keluarga yang hangat dan penuh kasih sayang, serta menjunjung tinggi nilai-nilai kejujuran dan kebenaran. Dengan kepercayaan diri, individu dapat berpikir dan bertindak antisipatif, artinya apa yang dipikirkan cenderung melihat ke arah masa depan.

Meski hubungan saling percaya di dalam keluarga subjek berbeda namun kedua subjek mampu menunjukkan rasa percaya diri yang tinggi. Hal ini bukan berarti kedua subjek kompeten melakukan segala hal namun lebih merujuk pada adanya beberapa aspek dari kehidupan individu tersebut dimana ia merasa memiliki kompetensi, yaitu mereka yakin bahwa dirinya bisa karena didukung oleh pengalaman, potensi aktual, prestasi serta harapan yang realistik terhadap diri sendiri (Rini dalam Hakim, 2007). Mereka percaya terhadap kemampuan diri, menilai keberhasilannya melalui standar dan penilaian pribadi sehingga mereka tidak tergantung pada penilaian orang lain. Hal ini dapat dibuktikan dari perilaku subjek BAT mengenai kemampuan akademik yang dimiliki saat ini, ia mengaku kemampuan yang ia miliki sekarang adalah berkat dari usaha dan jerih payahnya seorang diri demi mendapatkan hasil yang ia inginkan. Baginya jika ia ingin mendapatkan hasil yang positif maka ia sendiri harus berusaha demi mendapatkan hal tersebut. Hanya saja kemampuan yang subjek miliki ini tidak dibarengi dengan kemampuannya dalam menempatkan potensi di depan umum karena subjek merasa itu bukanlah dirinya yang ia ketahui. Sedangkan pada subjek RA hal ini dapat dilihat ketika ia diminta menjadi perwakilan lomba yang belum pernah ia ikut sama sekali, dimana subjek awalnya takut namun ia kemudian meyakinkan diri bahwa dirinya bisa. Subjek juga tidak takut menunjukkan potensi yang ia miliki di depan umum karena menurutnya kegiatan semacam ini merupakan kesempatan bagus untuk meningkatkan kepercayaan diri. Sehingga dapat dikatakan kepercayaan dan penghargaan diri kedua subjek positif.

Dunbar \& Grotevant pernah melakukan penelitian pada tahun 2004 menyatakan bahwa dalam ranah keluarga, anak adopsi akan menghadapi kebingungan karena memiliki perbedaan dengan orang tua angkat dalam beberapa hal seperti perbedaan fisik, karakter, dan budaya, akan tetapi dalam penelitian ini permasalahan tersebut tidak dapat ditemukan. Hal ini dapat disebabkan karena kedua belah pihak baik keluarga adopsi maupun keluarga kandung masih berada pada suku atau ras yang sama dimana faktor fisik dan karakter keduanya tidak memiliki perbedaan yang mencolok. Subjek RA bahkan mengatakan dirinya sama sekali tidak menyangka jika dirinya anak adopsi karena ia merasa tidak ada perbedaan fisik antara dirinya dengan orang tua adopsi, ia malah beranggapan dirinya memiliki kemiripan fisik dengan orang tua adopsi.

Dalam penelitian ini, kebingungan identitas hanya terjadi pada subjek BAT karena ia menemukan perbedaan antara kondisi keluarganya dengan informasi yang disampaikan orang lain padanya. Informasi yang ia dapatkan adalah kedua orang tuanya sudah meninggal dunia dan ia memiliki dua orang kakak sedangkan kondisi keluarga yang ia ketahui adalah kedua orang tuanya masih hidup hanya saja mereka sudah bercerai. Perbedaan ini kemudian membuat subjek kebingungan akan identitasnya namun karena subjek berani mencari dan menghubungkan informasi-informasi yang ia dapat, ia kemudian mengetahui kondisi yang terjadi. Dari berbagai informasi ini subjek kemudian mulai menemukan siapakah dirinya. Sedangkan pada subjek RA permasalahan ini tidak ditemukan karena dirinya merupakan anak tunggal dan orang tua mengontrol penuh lingkungan sekitar agar tidak memberikan kecurigaan 
pada subjek mengenai status adopsi. Hasil ini berarti mematahkan temuan yang dilakukan oleh Colaner \& Kranstuber (2010) yang mengatakan bahwa dalam ranah keluarga anak adopsi akan dihadapkan dengan perbedaan struktur keluarga dibandingkan dengan teman sebayanya, dalam proses pembentukan identitas, perbedaan ini berpotensi membawa anak kearah kebingungan identitas.

Mengenai status adopsi, kedua subjek mampu menghargai dirinya sebagai anak adopsi karena kondisi ini bukanlah sebuah aib yang perlu ditutup-tutupi. Hal ini menunjukkan penghargaan diri subjek sehat, artinya mereka mengenal dirinya sendiri dengan segala keterbatasan yang dimiliki namun tetap tidak merasa malu akan keterbatasan itu dan memandang keterbatasannya sebagai suatu realita. Kedua subjek melihat adopsi sebagai takdir yang diberikan Tuhan padanya sehingga mereka merasa bersykur karena sudah ada orang yang mau merawat dan membesarkannya. Proses pencarian identitas diri pada kedua subjek sebelum dan sesudah mengetahui dirinya anak adopsi tidak berdampak besar. Hanya saja pada subjek BAT ia sempat mengalami kebingungan identitas namun itu dapat ia atasi dengan baik sedangkan pada subjek RA bahkan tidak ditemukan dampak sama sekali. Subjek RA beranggapan ia cukup mengatahui informasi yang perlu ia ketahui dan tidak tertarik untuk menggali identitas dirinya lebih dalam. Hal ini sesuai dengan penelitian Grotevant dan Von Korff (2011) yang menyatakan proses pembentukan identitas lebih banyak terjadi pada masa remaja dengan segala faktor dan konsekuensi yang didapatkan namun bagi anak adopsi tugas pembentukan identitas diri tersebut harus ditambah dengan mengintegrasikan status adopsi ke dalam definisi diri.

\section{Proses pembentukan identitas-komitmen}

Aspek kedua dalam proses pembentukan identitas diri adalah komitmen. Pada tabel 2 dapat diketahui bahwa kedua subjek menunjukkan komitmen yang berbeda. Subjek BAT mampu menunjukkan karkateristik individu yang memiliki komitmen karena ia mampu memberikan perhatian lebih terhadap pilihan yang ia pilih, sedangkan subjek RA mengindikasikan individu yang memiliki pilihan atau tujuan namun tidak memberikan komitmen yang kuat.

Tabel 2. Proses komitmen

\begin{tabular}{lll}
\hline & Subjek BAT & Subjek RA \\
\hline Komitmen & - Hasil evaluasi diri dijadikan sebagai & - Tujuan belum jelas \\
& tujuan yang ingin dicapai & - Usaha untuk mencapai tujuan masih \\
& - Memberikan perhatian lebih dan & kabur \\
& melaksanakan usaha yang jelas demi & - Kurang memberikan perhatian dan \\
& mencapai tujuan & usaha untuk mencapai tujuan \\
& - Tidak takut gagal & \\
\hline
\end{tabular}

Desmita (2016) menyatakan terdapat dua kemungkinan yang dapat terjadi mengenai komitmen individu, pertama jika individu mampu menentukan alternatif yang ia pilih kemudian berusaha mempertahankan pilihan tersebut maka aspek identitas yang dimiliki individu akan berguna untuk mengarahkan perilaku di masa depan.
Kemungkinan kedua adalah ketika individu belum mampu menunjukkan komitmennya maka akan memunculkan sifat ragu-ragu, tindakannya terus berubah-ubah, tidak terarah dan menganggap komitmen personal saat ini bukanlah suatu hal yang penting. 
Berdasarkan penjelasan yang telah diuraikan di atas, ditemukan perbedaan minat ekplorasi dan komitmen pada kedua subjek dalam menemukan identitas diri. Dalam penelitian ini subjek BAT berada pada status identity achievement karena ia mampu menunjukkan minat eksplorasi yang tinggi sehingga membuatnya berada pada tahap eksplorasi (in crisis) dan memberikan komitmen terhadap hasil dari eksplorasi yang ia lakukan. Identity achievement adalah suatu keadaan dimana individu sedang mengalami eksplorasi dan memiliki tekad untuk menghadapinya dengan baik. Keberadaan eksplorasi ini mendorong dirinya untuk membuktikan bahwa ia mampu melewatinya dengan baik meski harus melewati banyak kegagalan demi menemukan identitas dirinya yang optimal.

Pada subjek RA, ia berada pada status identity moratorium karena ia sedang melakukan eksplorasi atau (in crisis) namun tidak memberikan komitmen terhadap eksplorasi yang ia lakukan. Subjek menyadari adanya suatu krisis yang harus ia selesaikan namun ia tidak mau melakukannya. Hal ini bisa disebabkan subjek masih dikuasai oleh prinsip kesenangan dan egoisme pribadi. Apa yang ia lakukan seingkali menyimpang dan tidak pernah sesuai dengan masalahnya, akibatnya ia mengalami stagnasi perkembangan. Subjek seharusnya telah mencapai tahap perkembangan yang lebih maju namun karena ia terus menerus tidak mau menghadapi krisisnya maka ia hanya bertahan dalam tahap itu. Kemungkinan yang lain ialah subjek memang tidak menyadari tugasnya namun juga tidak memiliki komitmen. Hal ini bisa disebabkan karena orang tua kurang memberikan rangsangan yang mengarahkan subjek untuk menyadari tugas perkembangannya pada masa itu

\section{Sumberpembentu identitas diri}

Pada kedua subjek, sumber acuan yang paling berpengaruh dalam proses pembentukan identitas diri secara berurutan adalah keluarga adopsi, reference group dan keluarga kandung. Pada anak adopsi, peran orang tua dapat mereka dapatkan dari dua keluarga yaitu dari keluarga kandung maupun dari keluarga adopsi. Pada penelitian ini, peran keluarga kandung hanya berdampak pada subjek BAT karena mereka sudah mengetahui kondisi adopsi subjek dan saat ini tinggal bersama sedangkan pada subjek RA ia belum pernah berinteraksi dengan keluarga kandung sejak ia diadopsi sehingga peran keluarga kandung kurang begitu besar.

Tabel 3. Sumber acuan

\begin{tabular}{llll}
\hline & Subjek BAT & Subjek RA \\
\hline Keluarga & - Memiliki peran besar & - Peran orang tua adopsi besar \\
adopsi & Pandangan subjek pada ibu adopsi & - Pandangan subjek pada orang tua \\
& negative karena sering mendapat & adopsi positif dan merasa bersyukur \\
& perlakuan kasar dan kekerasan verbal & karena mau mengadopsi dna merawat \\
& serta fisik & hingga sekarang & \\
& - Pandangan subjek pada bapak adopsi & & \\
Keluarga & positif karena sangat baik dan sayang & & \\
kandung & Peran keluarga kandung masih ada & - Subjek mengetahui keluarg \\
& dan berasal dari kaka perempuan yang & akndungnya namun enggan mencari \\
& merupakan satu-satunya keluarga & tahu & \\
Reference group & yang masih hidup & & \\
& Peran lingkungan sosial dan teman & - Peran teman bermain sangat tinggi \\
& bermain ada sebagai langkah subjek & karena banyak perilaku yang subjek \\
Significant other & berinteraksi dengan orang baru & tiru dan sangat tergantung kelompok \\
\hline
\end{tabular}


Pada subjek BAT, peran keluarga kandung didapat dari kakak perempuannya karena semua anggota keluarganya sudah meninggal dunia. Di samping itu karena keluarga kandung dan keluarga adopsinya masih memiliki hubungan saudara, subjek di adopsi oleh pamannya sendiri, keluarga adopsi tidak membatasi hubungan mereka dan mengizinkan mereka tinggal bersama. Subjek BAT merasa nyaman dan percaya kakak perempuannya karena memiliki banyak kesamaan baik dari hobi dan sifat. Subjek juga menghargai dan menerima nasihat-nasihat yang kakaknya berikan.

Peranan keluarga adopsi pada kedua subjek cukup positif, mereka menghargai dan menyayangi orang tua adopsinya serta sudah menganggap sebagai orang tua sendiri. Pada subjek BAT lebih menghormati bapak adopsi karena sangat menyayanginya dan selalu memberikan nasihat yang terbaik baginya. Hanya saja penilaian subjek pada ibu adopsinya cukup negatif karena ketika kecil sang ibu sangat membatasi perilaku subjek serta pernah melakukan kekerasan fisik maupun verbal padanya. Pengalaman ini kemudian menyebabkan subjek menjadi pendiam dan kesulitan beradaptasi dengan lingkungan baru. Selain itu, keluarganya kurang terbuka satu sama lain dan beberapa anggota keluarga cenderung meremehkan kemampuan subjek sehingga membuat subjek tidak percaya diri. Beruntungnya subjek mampu menghadapi krisis ini dan rasa percaya dirinya mulai meningkat.

Pada subjek RA, hubungan antara keluarga dan dirinya tidak dipenuhi dengan konflik keluarga. Hubungan dalam keluarga terjalin dengan baik dan penuh rasa saling percaya. Hal ini membuat subjek memiliki hubungan yang baik pula pada lingkungan sekitar. Subjek RA mudah beradaptasi dengan lingkungan serta mudah menjalin hubungan orang baru. Menurut Papalia (2004) hubungan remaja dengan orang tua yang buruk akan berpengaruh terhadap hubungan remaja dengan lingkungan di luar rumah. Remaja yang terikat secara aman pada orang tua semasa kecil, cenderung memiliki hubungan positif dengan lingkungan pergaulannya daripada remaja yang masa kecilnya memiliki konflik dengan orang tua (Santrock, 2003).

Sumber lain yang berpengaruh dalam pencarian identitas kedua subjek adalah reference group (kelompok-kelompok yang terbentuk ketika memasuki masa remaja) yaitu teman sebaya. Dampak teman sebaya lebih terlihat pada subjek RA subjek merupakan individu yang mudah beradaptasi dengan lingkungan sehingga memiliki banyak teman sedangkan subjek BAT lingkup pertemanannya lebih sempit. Subjek RA cenderung melakukan konformitas terhadap teman sebaya dimana ia mulai berperilaku dan mengubah sikap agar sesuai dengan kelompoknya.

\section{Simpulan dan Saran}

\section{Simpulan}

Berdasarkan hasil penelitian dan pembahasan yang telah dipaparkan sebelumnya, maka dapat ditarik kesimpulan sebagai berikut.

1. Eksplorasi identitas kedua subjek berada pada tahap in crisis dimana keduanya sedang menelaah pertanyaan-pertanyaan seputar identitas, namun komitmen yang diberikan subjek BAT lebih nyata dibandingkan subjek RA yang cenderung kabur. Perbedaan ini dipengaruhi oleh inisiatif diri, pengalaman masa kecil, tuntuntan, dukungan orang tua selama subjek mencari identitas serta tuntutan lingkungan sekitar terhadap identitas yang dipilih. Individu yang mampu menentukan alternatif yang dipilih kemudian berusaha mempertahankan pilihan tersebut maka aspek identitas yang dimiliki individu akan berguna 
untuk mengarahkan perilaku di masa depan. Sebaliknya apabila individu tersebut ragu-ragu maka tindakannya cenderung berubah-ubah dan menganggap komitmen bukanlah suatu hal yang penting.

2. Sumber yang banyak berpengaruh dalam proses pencarian identitas diri kedua subjek secara berurutan berasal dari keluarga adopsi, reference group yang dalam hal ini adalah teman sebaya lalu keluarga kandung.

\section{Saran}

Berdasarkan kesimpulan yang telah disebutkan sebelumnya, saran yang dapat diberikan yaitu:

1. Bagi subjek penelitian

Aspek eksplorasi sudah berada pada in crisis dimana keduanya sudah mau mencari informasi-informasi penting seputar dirinya. Hanya saja kemampuan ini perlu diimbangi dengan adanya pemberian komitmen yang kuat agar tujuan atau alternatif yang dipilih dapat tercapai. Apabila subjek masih belum yakin dengan ekplorasi dan komitmen yang akan dilakukan maka subjek dapat meminta bantuan kepada sumber lain untuk menguatkan pilihannya dan tidak salah arah.

2. Bagi peneliti selanjutnya

diperlukan penelitian mengenai identitas diri pada remaja adopsi dengan mempertimbangkan konteks yang lebih spesifik (misalnya status sosial ekonomi, budaya dan tingkat pendidikan) baik dari anak adopsi maupun orang tua adopsi karena masih banyak informasi yang dapat digali disana.

\section{Daftar Pustaka}

Adel, B. \& Rustiyarso, A. Z. (2018). Model adopsi bagi keluarga yang tidak mempunyai anak. Jurnal Pendidikan dan Pembelajaran, 7(1).

Child Welfare Information Gateaway. (2013). Impact of adoption on adopted persons. Washington. US: Children's Bureau

Child Welfare Information Gateaway. (2013). Working with birth and adoptive families to support open adoption. Washington, US: Children's Bureau

Desmita. (2016). Psikologi perkembangan. Bandung: Remaja Rosdhakarya.

Hidayah, N \& Huriati. (2016). Krisis identitas diri pada remaja "identity crisis of adolscences". Jurnal Wawasan Keislaman, 10(1).

Marcia, J. E. (1966). Development and validation of ego identity status. Journal of Personality and Social Psychology, 3(5), 551-558.

Peraturan Pemerintah Republik Indonesia No. 54 Tahun 2007 Pelaksanaan Pengangkatan Anak. Kementrian Pemberdayaan Perempuan dan Perlindungan Anak Republik Indonesia. Jakarta.

Santrock, J. W. (2003). Adolescence edisi keenam. Jakarta: Erlangga

Santrock, J. W. (2012). Perkembangan masa bidup edisi ketigabelas jilid 1. Jakarta : Erlamgga

Suadi, A. \& Candra, M. (2016). Politik bukum: Perspektif bukum perdata dan pidana islam serta ekonomi syariah. Jakarta : Kencana.

Yustiana. (2017). Legal arrangements regarding the adoption of children in indonesia. International Journal of Humanities and Social Science Invention, 6(2), 24-44. 